Bangladesh J. Bot. 43(3): 293-299, 2014 (December)

\title{
MORPHOLOGICAL VARIABILITY OF ACORNS AND ITS TAXONOMIC SIGNIFICANCE IN QUERCUS L. FROM TURKEY
}

\author{
Y BAKIŞ* AND MT BABAÇ \\ Department of Biology, Faculty of Science, Abant İzet Baysal University, Bolu 14280, Turkey
}

Key words: Fruit Morphology, Oak, Variation, Morphometrics, Principal component analysis

\begin{abstract}
Morphological variations of acorn among and within the groups of Quercus species were studied. A total of 617 acorns belonging to 14 species representing all 3 sections of Quercus L. (Fagaceae) in Turkey were examined in this study. Specimens were collected from 47 different populations over both Anatolian and Thrace part of Turkey. Principal component analysis was used to analyze the morphological characteristics of acorns. Results obtained from this study demonstrate the use of morphological characters in differentiating the taxa of Quercus and Cerris sections studied. Another important finding is the introgression among the acorns of species within Quercus section.
\end{abstract}

\section{Introduction}

Turkey has long been blessed by the diversity, abundance, and beauty of oaks. Great variety of oaks present in both Anatolian and European parts of Turkey ranging from Mediterranean, Aegean, and Black Sea coastal regions to towering coastal and interior mountains. The group occupies 25 per cent of the forest area of Turkey (Ertaş 1995). The Quercus in Turkey is divided into three sections according to Flora of Turkey and East Aegean Islands (Davis et al. 1965-1985).

An acorn is the fruit of the oak, which is an oval nut growing in a woody cup or cupule. Nut consists of a hard and indehiscent shell inclosing a kernel. Cupule is a massive, robust and often compound envelope of fruits (Fey and Endress 1983).

Acorns vary greatly in size between species, subspecies and even within the same population depending on the taxa and its environment (Bonito et al. 2011, Dufour-Dror and Ertaş 2002, Galván et al. 2012, Ramírez-Valientea et al. 2009). Within the genus Quercus, Q. ithaburensis probably has the largest acorns, while Q. petraea has the smallest (Pavlik 1991). The fruits of the species within section Cerris are matured in two years, and contain a large amount of fat, while the species of Quercus section produce small fruits without excess amount of fat. The acorn maturation as a character is commonly used to differentiate major groups within Quercus in Flora of Turkey and the East Aegean Islands (Davis and Cullen 1979).

Quercus has attracted the attention of the evolutionists for its very poor reproductive development (Bacilieri et al. 1996). Among-tree relationships based on fruit/bud characters were found to be significantly different from among-tree relationships based on leaf characters of the genus (Jensen 1989, 1992).

Vegetative characters are often viewed as having less taxonomic utility than reproductive characters (Ornduff 1978, Sivarajan and Robson 1991). However, in the subgenus Quercus, the leaf alone may be sufficient for discrimination purposes since it varies significantly from species to species with respect to shape, size and hairiness (Viscosia et al. 2009). Morphological studies based on acorn characters are incredibly few. In a few recent studies on acorn morphology (Jensen 1992, Jensen and Tomlinson 2003) some fruit/bud characters were found to be useful in identifying

*Author for correspondence: <bakis_y@ibu.edu.tr>. 
oak species with multivariate analysis. Several acorn characters like length, width, diameter and weight were preferred by some other studies (Barzdajn 2002; Galván et al. 2012, Ivanković et al. 2011, Major 2002, Nikolić and Orlović 2002).

Presence of a rich and diverse flora of oaks ranging from coastal regions to top of high mountains, diversity in shape and size of acorns (Jensen 1980, 1989), and availability of various analyzing techniques motivated us to perform this study. Can morphology of acorns be distinctive for at least some groups of Quercus? To answer that, this study has aimed to evaluate the morphological variations among acorns of different groups of Quercus species as well as acorns of closely related species. Present authors have tried to extract principal components and plot the specimens onto a two dimensional graph. By this way it would be possible to show whether they are morphologically different.

\section{Materials and Methods}

Acorns were picked up directly from trees. Acorn samples were chosen randomly among the mature and normal shaped ones during sampling process. Authors paid attention to select acorns with cupules, since characters of coupling cupule would also be useful.

Samples were collected from the different locations with respect to phytogeographical regions when possible (Table 1). Each location represents an oak population of one or more species. Each species were preferably represented by 4 populations, each population by 3 trees, and each tree by 5 acorns. A number of 47 populations belonging to 14 species were sampled from 43 distinct locations. Information on nomenclature, populations, plant samples and locations are represented in Table 1. Acorns were treated as operational taxonomic units (OTUs). Measurements of 13 characters were taken from a total of 617 acorns. These characters are summarized in Table 2 and described in Fig. 1. All characters were quantitative continuous. Longest cupule scale was measured for cupule scale length character. Since only regularly shaped acorns were included in the study, authors assumed that acorn has radial symmetry.
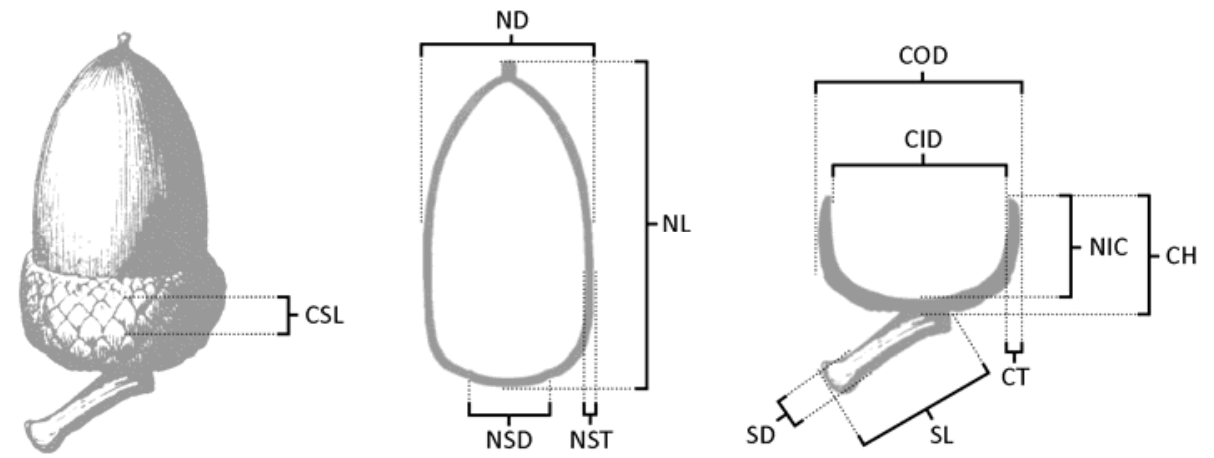

Fig. 1. Morphological characters of the acorn $(\mathrm{NL}=$ Nut length, ND $=$ Nut diameter, NSD $=$ Nut scar diameter, NST $=$ Nut shell thickness, $\mathrm{NOC}=$ Nut out of cupule, $\mathrm{NIC}=$ Nut in cupule (Cupule depth), $\mathrm{CH}$ $=$ Cupule height, $\mathrm{CID}=$ Cupule inner diameter, $\mathrm{COD}=$ Cupule outer diameter, $\mathrm{CT}=$ Cupule thickness, $\mathrm{CSL}=$ Cupule scale length, $\mathrm{SL}=$ Stalk length, $\mathrm{SD}=$ Stalk diameter).

In order to view the groupings or the clusters for the classification of acorns, the morphological characteristics of 617 acorns belonging to 14 oak species from Turkey were analyzed by Principal Component Analysis (PCA) module using STATISTICA version 8.0. A matrix of raw data with quantitative variables was needed to be treated by PCA. Therefore, a data 
Table 1. Samples with taxonomy and locality information.

\begin{tabular}{|c|c|c|c|c|c|c|}
\hline Taxon & Population & (n) & Station & $\begin{array}{l}\text { Altitude } \\
(\mathrm{m})\end{array}$ & $\begin{array}{l}\text { Coordinates } \\
\mathrm{N}\end{array}$ & $\mathrm{E}$ \\
\hline \multicolumn{7}{|l|}{ Section Ilex Loudon } \\
\hline \multirow[t]{3}{*}{ Q. aucheri Jaub. \& Spach } & AUC114 & 3 & 114 & 90 & $37^{\circ} 44.967$ & $029^{\circ} 16.360$ \\
\hline & AUC117 & 3 & 117 & 180 & $37^{\circ} 33.558$ & $028^{\circ} 04.047$ \\
\hline & AUC118 & 2 & 118 & 300 & $37^{\circ} 32.889$ & $028^{\circ} 05.310$ \\
\hline \multirow[t]{4}{*}{ Q. coccifera $\mathrm{L}$. } & COC128 & 3 & 128 & 140 & $39^{\circ} 29.722$ & $026^{\circ} 21.148$ \\
\hline & $\mathrm{COC} 166$ & 3 & 166 & 1415 & $36^{\circ} 51.407$ & $033^{\circ} 16.702$ \\
\hline & $\mathrm{COC} 176$ & 3 & 176 & 710 & $37^{\circ} 26.291$ & $037^{\circ} 12.226$ \\
\hline & COC209 & 3 & 209 & 100 & $41^{\circ} 16.197$ & $028^{\circ} 40.196$ \\
\hline \multirow[t]{2}{*}{ Q. ilex $\mathrm{L}$. } & ILX113 & 3 & 113 & 110 & $37^{\circ} 41.905$ & $027^{\circ} 11.334$ \\
\hline & ILX206 & 3 & 206 & 60 & $41^{\circ} 09.136$ & $031^{\circ} 23.627$ \\
\hline \multicolumn{7}{|l|}{ Section Cerris Loudon } \\
\hline \multirow[t]{4}{*}{ Q. brantii Lindl. } & BRA156 & 3 & 156 & 1025 & $39^{\circ} 11.541$ & $039^{\circ} 42.114$ \\
\hline & BRA158 & 3 & 158 & 1135 & $39^{\circ} 03.650$ & $038^{\circ} 30.024$ \\
\hline & BRA081 & 1 & 81 & 1470 & $38^{\circ} 13.157$ & $041^{\circ} 52.131$ \\
\hline & BRA172 & 3 & 172 & 500 & $36^{\circ} 28.514$ & $036^{\circ} 16.735$ \\
\hline \multirow[t]{4}{*}{ Q. cerris $\mathrm{L}$. } & CER137 & 3 & 137 & 1065 & $40^{\circ} 09.950$ & $035^{\circ} 07.235$ \\
\hline & CER181 & 3 & 181 & 1470 & $38^{\circ} 12.485$ & $035^{\circ} 53.293$ \\
\hline & CER210 & 3 & 210 & 40 & $41^{\circ} 52.450$ & $027^{\circ} 57.408$ \\
\hline & CER200 & 3 & 200 & 500 & $39^{\circ} 15.279$ & $026^{\circ} 04.446$ \\
\hline \multirow[t]{4}{*}{ Q. ithaburensis Decne. ex Decne. } & ITH216 & 2 & 216 & 50 & $40^{\circ} 38.848$ & $026^{\circ} 14.970$ \\
\hline & ITH186 & 2 & 186 & 1140 & $39^{\circ} 04.457$ & $029^{\circ} 27.465$ \\
\hline & ITH169 & 1 & 169 & 1110 & $36^{\circ} 33.774$ & $033^{\circ} 54.779$ \\
\hline & ITH124 & 3 & 124 & 70 & $39^{\circ} 03.309$ & $026^{\circ} 53.490$ \\
\hline \multirow[t]{4}{*}{ Q. libani Olivier } & LIB151 & 3 & 151 & 1310 & $39^{\circ} 33.334$ & $040^{\circ} 02.531$ \\
\hline & LIB146 & 1 & 146 & 1500 & $37^{\circ} 54.411$ & $042^{\circ} 56.096$ \\
\hline & LIB159 & 3 & 159 & 920 & $39^{\circ} 12.550$ & $038^{\circ} 35.229$ \\
\hline & LIB087 & 1 & 87 & 1490 & $38^{\circ} 58.110$ & $041^{\circ} 05.685$ \\
\hline \multirow[t]{4}{*}{ Q. trojana Webb. } & TRO163 & 3 & 163 & 1110 & $37^{\circ} 09.275$ & $033^{\circ} 25.859$ \\
\hline & TRO193 & 3 & 193 & 245 & $39^{\circ} 48.725$ & $027^{\circ} 37.757$ \\
\hline & $\mathrm{TRO} 220$ & 3 & 220 & 20 & $37^{\circ} 25.358$ & $027^{\circ} 13.200$ \\
\hline & TRO185 & 3 & 185 & 970 & $39^{\circ} 21.732$ & $030^{\circ} 02.756$ \\
\hline \multicolumn{7}{|l|}{ Section Quercus (Endl.) Örsted } \\
\hline \multirow[t]{3}{*}{ Q. frainetto Ten. } & FRA208 & 3 & 208 & 80 & $41^{\circ} 12.036$ & $029^{\circ} 00.825$ \\
\hline & FRA191 & 3 & 191 & 340 & $39^{\circ} 49.444$ & $027^{\circ} 48.992$ \\
\hline & FRA187 & 2 & 187 & 700 & $39^{\circ} 08.550$ & $028^{\circ} 43.917$ \\
\hline \multirow[t]{4}{*}{ Q. infectoria Olivier } & INF163 & 3 & 163 & 1110 & $37^{\circ} 09.275$ & $033^{\circ} 25.859$ \\
\hline & INF145 & 3 & 145 & 1500 & $37^{\circ} 54.411$ & $042^{\circ} 56.096$ \\
\hline & INF199 & 3 & 199 & 40 & $39^{\circ} 04.500$ & $026^{\circ} 56.805$ \\
\hline & INF183 & 3 & 183 & 650 & $40^{\circ} 27.452$ & $030^{\circ} 21.736$ \\
\hline \multirow[t]{2}{*}{ Q. macranthera Fisch. \& C.A. Mey. ex Hohen. } & MAC140 & 3 & 140 & 1535 & $39^{\circ} 57.091$ & $039^{\circ} 37.896$ \\
\hline & MAC150 & 3 & 150 & 1975 & $39 \circ 51.962$ & $040^{\circ} 37.616$ \\
\hline \multirow[t]{3}{*}{ Q. petraea (Matt.) Liebl. } & PET115 & 3 & 115 & 290 & $37^{\circ} 53.422$ & $027^{\circ} 21.973$ \\
\hline & PET087 & 2 & 87 & 1490 & $38^{\circ} 58.110$ & $041^{\circ} 05.685$ \\
\hline & PET204 & 3 & 204 & 700 & $40^{\circ} 18.258$ & $032^{\circ} 25.869$ \\
\hline \multirow[t]{3}{*}{ Q. pubescens Willd. } & PUB133 & 2 & 133 & 1080 & $40^{\circ} 43.991$ & $034^{\circ} 34.512$ \\
\hline & PUB102 & 3 & 102 & 1050 & $38^{\circ} 58.078$ & $030^{\circ} 06.433$ \\
\hline & PUB182 & 3 & 182 & 660 & $40^{\circ} 31.450$ & $031^{\circ} 04.973$ \\
\hline \multirow[t]{4}{*}{ Q. robur $\mathrm{L}$. } & ROB084 & 2 & 84 & 1480 & $38^{\circ} 33.442$ & $042^{\circ} 05.492$ \\
\hline & ROB140 & 3 & 140 & 1535 & $39^{\circ} 57.091$ & $039^{\circ} 37.896$ \\
\hline & ROB208 & 2 & 208 & 80 & $41^{\circ} 12.036$ & $029^{\circ} 00.825$ \\
\hline & ROB189 & 3 & 189 & 365 & $39^{\circ} 14.093$ & $028^{\circ} 06.501$ \\
\hline
\end{tabular}


matrix was compiled from original measurements. For each character the average of 5 acorns were calculated. Each acorn (as OTUs) corresponded to a row and each character (variable) to a column within the data matrix. All 617 OTUs were used for the first analysis. Secondary data matrices were derived from the main matrix by dividing it into three parts according to the OTUs of three sections (Quercus, Ilex and Cerris). To show the variation within the sections, analysis was also performed for smaller groups of OTUs grouped by 3 sections. All 13 variables were chosen as 'variables for analyses'. Section names were used as 'grouping variables' when defining plot markers in the analysis of all OTUs. Species names were used in the analysis of Quercus, Ilex and Cerris sections for 'grouping variables'. Two dimensional projections of all OTUs, and Quercus, Ilex and Cerris sections were generated and shown in Fig. 2. Analyses were plotted by two factors with the highest percentages, for explaining the most of the data. Four PCA plots were calculated based on measurements of morphological characters. The plots of four analyses were represented in Fig. 2. To show the relationships among the characters, correlations were calculated.

\section{Results and Discussion}

In this study the components - also known as factors - in PCA plots, showed approximately $69 \%$ of the total variance is accounted for all by components 1 and 2 combined and $63 \%$ in the Ilex plot (Fig. 2.B). In the Quercus and Cerris plots, the coverage of the accounted variance was less than $60 \%$. In PCA of morphological measurements, first principal component is generally
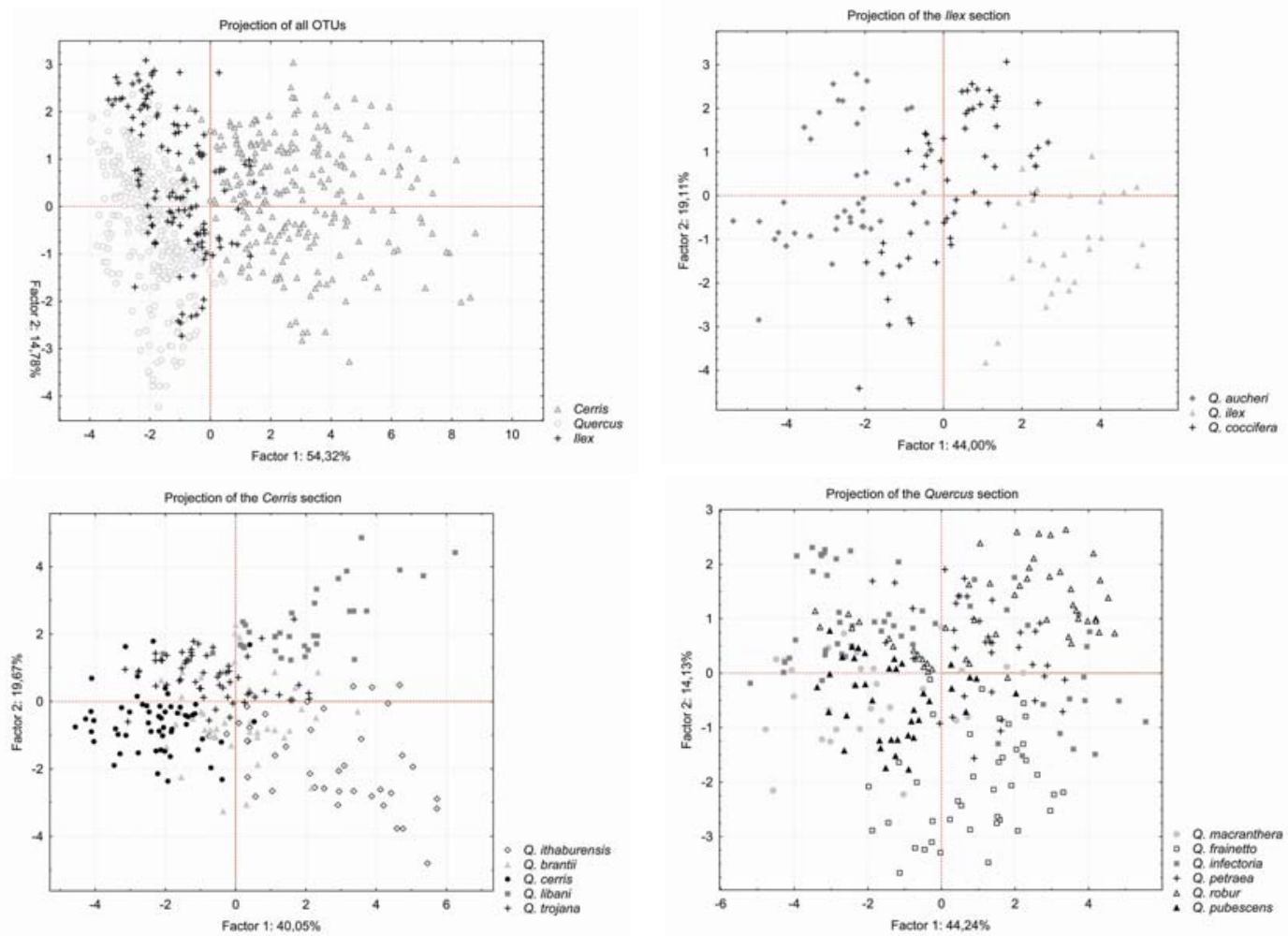

Fig. 2. PCA Projections of all sections (A), of Ilex section (B), of Cerris section (C) and of Quercus section (D) according to first two factors (principal components). 
taken as a measure of size, and subsequent principal components are then describing various aspects of shape (Cadima and Jolliffe 1996). Size dependent characters especially nut lengths and widths were generally used to estimate acorn volume (Aizen and Patterson 1990). On the other hand, it is not possible to predict the resolution of the other components since the percentage values of these components are very close to each other.

In this study, two bigger sections, Quercus and Cerris, were separated by the first factor which ordinates acorns by their sizes. Within the Cerris section, Q. ithaburensis and Q. libani, the two species with biggest acorns were scattered on the opposite site of Quercus and Ilex sections. This is because the fruits of species within section Cerris are matured in two years, and contains a quantity of fat, while Quercus section is represented with small fruits without excess amount of fat. Therefore, this study supports the view that first component generally ordinates OTUs according to their size. The first component accounts for $69 \%$ of the total variation and has the highest values of coefficients (not included in the study) among the cupule characters. Thus, PCA finds variations in cupule characters most significant (Fig. 2).

Principal component analysis plots, by the use of highest two factors, were explained more than half of the data which is an acceptable value for most cases. However, Quercus and Cerris plots were found to be approximately $10 \%$ less than complete plot. This is basically caused by the variation within Cerris and Quercus sections. Cerris section is particularly known by their reproductive strategy, and biennial maturation. Biennial maturation specialize acorns to survive under different climatic conditions. This simply causes a variety of morphological changes in characteristics of acorns to adapt to variable and unpredictable climatic conditions, characteristic of the Mediterranean climate (Elena-Rossello et al. 1993). Beside the complexity and variation in morphological features of its acorns, Cerris section is the simplest to discriminate from other sections by their acorn size and biennial maturation. Only some acorns belonging to Ilex section might penetrate into the Cerris group. They were the most common acorns of $Q$. aucheri whose inclusion in Ilex section was seemed to us suspicious. By their appearance, $Q$. aucheri acorns resemble those of the Cerris section substantially. Differentiation and grouping of acorns of different species in the results of PCA is simpler than those of the Quercus section. OTUs show a triangular distribution over the plot (Fig. 2A). Q. ithaburensis, Q. libani and Q. cerris are on the corners of the triangle, and Q. trojana is between the two corners of $Q$. libani and $Q$. cerris. Only the exception is $Q$. brantii, which is scattered widely in the middle and overlaps with three other species.

Ilex section, with its three species, is the least complex section by number. Each of the three species are scattered almost equally and parallel to each other in the PCA plot (Fig. 2B). In the same plot, $Q$. coccifera spreads in the two other species. $Q$. aucheri scattered at one side with biggest acorns in the section and $Q$. ilex at the other side with smallest acorns.

Quercus section is the most problematic group in the genus. Hybridization takes place among the species of this section more frequently (Borazan and Babac 2003, Viscosia et al. 2009). In taxonomic discrimination, the biggest problems occur especially in section Quercus (Bruschi et al. 2000). Although PCA separated some species distinctly, most are overlapping with other species. However, the sample size is not sufficient and excessive number of species is covered to state something about hybridization among these species. Although PCA analyses could not separate the six taxa belonging to the section Quercus clearly, the results support the group of $Q$. robur, $Q$. macranthera and $Q$. frainetto and that of $Q$. infectoria and $Q$. robur and isolated position of $Q$. petreae from the section. Both $Q$. infectoria and $Q$. robur have two subspecies. Q. petraea has $\underline{3}$ three subspecies, but these are not differentiated in the plot. Overlapping positions of these three species ( $Q$. infectoria, Q. robur and Q. petraea) is remarkable. Comparing to Borazan and Babac 
(2003) in which morphological analysis of oak leaves were issued, we can say that acorn characters might also be useful in the separation of oak species.

Correlations among characters also give remarkable results. ND is found to be correlated with CID and COD. COD in Cerris section only the exception is which is below the level of significance. This is because certain species in this section have very thick and long scales while some other species with the same size have not (Borgardt and Nixon 2003). The same situation also occurs in NSD since ND and NSD are highly correlated. Correlation between CID and COD is as low as on the significance limit and CT is highly correlated with CSL because of the same thick scale reason. SL shows a negative correlation with most of the length and diameter characters in Ilex section. Q. aucheri acorn has the largest size without a stalk, $Q$. coccifera has short or no stalk at all and $Q$. ilex has the longest stalks.

Results obtained in this study demonstrate the usefulness of acorn morphology in delimitation of some Quercus. Acorn shape characteristics are found valuable taxonomically especially at the section level and also for small groups of species. Analysis of acorn shape variation might be most successfully applied in Cerris section for taxonomic delimitation.

This study has proved the taxonomic utility of fruit characters in Fagaceae and also states that relationships among the characters can be explained by the use of geometric morphometric methods.

\section{Acknowledgements}

Thanks are due to Ali Nihat Gökyiğit Education, Culture, Art and Protection of Wildlife Foundation for providing funding for our project and Dr. Emel Uslu, Dr. Mustafa Ünal and Dr. Bahadır Altıntaş for providing technical support and late Aydın Borazan for providing scientific comments for this study.

\section{References}

Aizen MA and Patterson WA 1990. Acorn size and geographical range in the North American oaks (Quercus L.). J. Biogeography 17: 327-332.

Al Jassim RAM, Ereifej KI, Shibli RA and Abudabos A 1998. Utilization of concentrate diets containing acorns (Quercus aegilops and Quercus coccifera) and urea by growing Awassi Lambs. Small Ruminant Research 29: 289-293.

Bacilieri R, Ducousso A, Petit RJ and Kremer A 1996. Mating system and asymmetric hybridization in a mixed stand of European Oaks. Evolution 50(2): 900-908.

Barzdajn W 2002. The variability of dimensions of Quercus robur L. and Quercus petraea (Matt.) Liebl. acorns in Poland. Dendrobiology 47: 21-24.

Bonito A, Varone L and Gratani L 2011. Relationship between acorn size and seedling morphological and physiological traits of Quercus ilex L. from different climates. Photosynthetica 49(1): 75-86.

Borazan A and Babac MT 2003. Morphometric leaf variation in oaks (Quercus) of Bolu, Turkey. Ann. Bot. Fenn. 40(4): 233-242.

Borgardt SJ and Nixon KC 2003. A Comparative Flower And Fruit Anatomical Study of Quercus Acutissima, A Biennial-Fruiting Oak From The Cerris Group (Fagaceae). Amer. J. Bot. 90(11): 15671584.

Bruschi P, Vendramin GG, Busotti F and Grossoni P 2000. Morphological and molecular differentiation between Quercus petraea (Matt) Liebl. and Quercus pubescens Willd. (Fagaceae) in northern and central Italy. Ann. Bot. 85: 325-333.

Cadima JFCL and Jolliffe IT 1996. Size- and shape-related principal component analysis. Biometrics 52: $710-716$

Davis PH and Cullen J 1979. The Identification of Flowering Plant Families, Including A Key to Those Native and Cultivated in North Temperate Regions. Cambridge University Press, Cambridge. 
Davis PH, Cullen J and Coode MJE 1965-1985. Flora of Turkey and the East Aegean Islands. Edinburgh University Press, Edinburgh.

Dufour-Dror JM and Ertaş A 2002. Cupule and acorn basic morphological differences between Quercus ithaburensis Decne. subsp. ithaburensis and Quercus ithaburensis subsp. macrolepis (Kotschy) Hedge et Yalt. Acta Botanica Malacitana 27: 237-294.

Elena-Rossello J, Rio Jd, Valdecantos JG and Santamaria I 1993. Ecological aspects of the floral phenology of the cork-oak ( $Q$ suber L.): why do annual and biennial biotypes appear? Ann. Forest Sci. 50(1): 114121.

Ertaş A 1995. The Oaks of Turkey. Journal of The International Oak Soc. 6: 33-42.

Fey SB, Endress PK 1983. Development and morphological interpretation of the cupule in Fagaceae. Flora 173: $451-468$.

Galván JV, Novo JJJ, Cabrera AG, Ariza D, García-Olmo J and Cerrillo RMN 2012. Population variability based on the morphometry and chemical composition of the acorn in Holm oak (Quercus ilex subsp. ballota [Desf.] Samp.). European J. Forest Res. 131(4): 893-904.

Ivanković M, Popović M and Bogdan S 2011. Acorn Morphometric Traits and Seedling Heights Variation of Pedunculate Oak (Quercus robur L.) from the Seed Stands in Croatia. J. For. Soc. Croatia 135(13): 4657.

Jensen RJ 1980. Morphological and phenolic variation in a tree species community of red oaks. Bulletin of the Torrey Bot. Club 107(3): 418-428.

Jensen RJ 1989. The Quercus falcata Michx. Complex in Land Between The Lakes Kentucky and Tennessee; a Study of Morphological Variation. The Amer. Midland Naturalist Journal 121: 245-255

Jensen RJ 1992. Morphometric Variation in Acorns From Two Red Oak Communities in Land Between The Lakes: Hybridization or Normal Variation? Fourth Annual Symposium on The Natural History of Lower Tennessee and Cumberland River Valleys proceedings. J. Tenn. Acad. Sci., Tennessee.

Jensen RJ and Tomlinson PT 2003. Leaves, acorns, and character variability in Quercus (Fagaceae). Botany 2003 Conference, Mobile, Alabama.

Kasaplıgil B 1992. Türkiye'nin Geçmişteki ve Bugünkü Meşe Türleri. Orman Bakanlığı Orman Genel Müdürlüğü Yayını, Ankara.

Major S 2002. Variability of Quercus robur L. and Quercus petraea (Matt.) Liebl. acorn size in the region of the Pomeranian plains. Dendrobiology 47: 25-31.

Manos PS, Doyle JJ and Nixon KC 1999. Phylogeny, biogeography, and processes of molecular differentiation in Quercus subgenus Quercus (Fagaceae). Molecular Phylogenetics and Evolution 12(3): 333-349.

Nikolić NP and Orlović SS 2002. Genotypic variability of morphological characteristics of English oak (Quercus robur L) acorn. Zbornik Matice srpske za prirodne nauke 102: 53-58.

Ornduff R 1978. Reproductive characters and taxonomy. Systematic Botany 3(4): 420-427.

Pavlik BM 1991. Oaks of California. Cachuma Press, California

Rakic S, Povrenovic D, Tesevic V, Simic M and Maletic R 2005. Oak acorn, polyphenols and antioxidant activity in functional food. Journal of Food Engineering 74: 416-423.

Ramírez-Valientea JA, Valladaresc F, Gilb L and Arandaa I 2009. Population differences in juvenile survival under increasing drought are mediated by seed size in cork oak (Quercus suber L.). Forest Ecology and Management 257(8): 1676-1683.

Samuel R 1999. Identification of hybrids between $Q$. petraea and Q. robur (Fagaceae): Results obtained with RAPD markers confirm allozyme studies based on the Got-2 locus. Plant Systematics and Evolution 217: $137-146$.

Sivarajan VV and Robson NKP 1991. Introduction to The Principles of Plant Taxonomy Oxford \& IBH, New Delhi.

Viscosia V, Fortinia P, Sliceb DE, Loya and Blasic C 2009. Geometric morphometric analyses of leaf variation in four oak species of the subgenus Quercus (Fagaceae). Plant Biosystems 143(3): 575-587.

Yaltırık F 1984. Türkiye Meşeleri Teşhis Klavuzu. Yenilik Basımevi, İstanbul. 